\title{
The Impact of Entrepreneurship on Performance In Public Sector Organizations with Application To the Egyptian Electricity Holding Company
}

\author{
Dr. Marwa Gaber Ahmed Fahim \\ Lecturer in Business Administration Department \\ \& Modern Academy for Computer Science \\ Management Technology in Maadi \\ Arab Republic of Egypt
}

\begin{abstract}
The success and prosperity of any country is directly tied to the performance of its public, private, and social voluntary sectors, separately and in combination. Governments are looking increasingly at business methods and goals for approaches to innovation, in order to achieve greater efficiency and improved performance. This paper argues that entrepreneurship is an essential alternative option to resolve inadequate government bureaucracies' performance, particularly in developing countries. The research provides a background analysis which describes the private sector entrepreneurial activities and principles that may be transferable to the public sector. The purpose of this study is to find out the aspects (supportive organizational characteristics) and key functions of entrepreneurship in public organizations and its impact on their performance, especially in light of the controversial debate in relevant literature regarding the correlation between the two variables.

Practical and empirical lessons in this research are drawn from the experience of the Egyptian Electricity Holding Company. The empirical results here - according to the executives' views - showed that there is a significant impact of entrepreneurial activities on organizational performance of the Egyptian Electricity Holding Company, with and without considering the moderating variables, and this in spite of what is proven concerning the minimal adoption of such activities by the company.

Eventually, the study proposed some managerial and administrative reforms to enhance entrepreneurship in the public sector and to improve its performance, particularly in Egypt. As well, it emphasized the importance of future public entrepreneurship research that could be conducted comparatively by taking into consideration various state-owned enterprises in multiple different countries. This will help to increase our understanding of the advantages and drivers of entrepreneurship across countries, thereby increasing the ability to generalize findings.

Keywords: Entrepreneurship, Entrepreneurs, Entrepreneurial Activities, Public Entrepreneurship, Entrepreneurial Government, Innovation \& Creativity, Organizational Performance, Public Sector Organizations, Public Service Reform, Egyptian Electricity Holding Company.
\end{abstract}

\section{Introduction}

There are three massive changes in the way economies work and how organizations within them operate; the rise of knowledge and technology-intensive jobs and industries, investment in knowledge-based assets,

* This article was submitted in October 2016, and accepted for publishing in February 2017. 
and increasing educated and well-qualified workforces. The primary driver is the growing demand for high value-added products and services from more advanced, diverse, and demanding customers (Brinkley, 2010: 4).

In this context, a major issue in many countries, particularly developing ones, appears to be the issue of civil service reform. Government needs to keep efficiency and effectiveness of the public sector while boosting accountability to its citizens. Therefore, there is an urgent need for administrative practices and managerial leaders who add new aspects and dimensions to the management of public sectors, in order to foster development and democracy. However, poor performance of public sectors is frequently reported in most developing countries. Consequently, entrepreneurship is presented as one answer to this problem (Fernando, 2005: 2). Hence, "entrepreneurial government" is emerging in which public managers have to play an innovative role for improving the performance of governments, especially in developing countries.

This paper argues that entrepreneurship in public organizations remains a potential path as an alternative choice to resolve inappropriate government performance, particularly in developing countries. The primary purpose here is to look at the potential role of innovation, based on the private sector entrepreneurial model, in enhancing the performance of public sector. The main objectives are to find out the key factors and roles of public entrepreneurship, and to propose measures for managerial and administrative reforms in developing entrepreneurial behaviors and activities to stimulate the performance of public sector organizations.

On the other hand, there have been endeavors over several decades to reform and promote government performance in Egypt. In this respect, forces of public entrepreneurship are significant for study, as they lead to improvements in the efficiency and effectiveness of the Egyptian public sector. Thus, this research attempts to extend our understanding regarding public entrepreneurship, as it explores the influence of entrepreneurship in a one public sector context. The study reports the entrepreneurial practices in a large and important state-owned enterprise working in a dynamic political and economic environment, which is the Egyptian Electricity Holding Company.

\section{Theoretical Framework}

\section{Problem Statement}

Entrepreneurship has been qualified as a fourth production factor in the macroeconomic production function. Actually it is the factor that creates wealth by mixing existing production factors in new ways (Stam, et al., 2009: 4). Entrepreneurship is a source of modification and innovation, and as such spurs improvements in performance, productivity, and economic competitiveness. As a key element in securing and retaining the competitiveness of developed countries, entrepreneurship is even more centric to the developing countries striving to attain competitiveness in international markets (United Nations, 2004: 3). Moreover, the entrepreneurial orientation should not be limited only to the private sector, as public organizations operate with limited resources and need to discover creative solutions to continue the provision of goods and services, in order to enhance their performance and respond to the rising demands of citizens. In this regard, Peter Drucker argues that "public-service institutions need to be entrepreneurial and innovative fully as much as any business does, indeed they may need it more" (Tosterud: 1). 
During the past years, in response to the critical public problems in different domains, and the economic, institutional, and ideological changes, as well as critiques of incompetent and costly governments, public sector reform has become an international claim and phenomenon. Currently, many developing countries are transitioning away from more centralized economic structures and implementing organizational changes to encourage successful entrepreneurship (Lucy \& Were, 2014: 345-346).

The purpose of this paper is to increase our knowledge and understanding of public entrepreneurship in general, by providing a framework for analyzing its relationship to private entrepreneurial practices, and then studying its influence on organizational performance, especially in light of the controversial debate in relevant literature regarding this correlation. Furthermore, the urgency of public sector reforms in Egypt has been an important issue on the national agenda for some time. Thus, this study tries to examine the usefulness of entrepreneurship in the public sector organizations in Egypt, and tries to identify the organizational characteristics that facilitate managers to act in an entrepreneurial manner, and finally it proposes some administrative and managerial reforms towards to ensure high performance and effective delivery of public services.

Therefore, this paper investigates a main research question which is:

\section{"To what extent does entrepreneurship contribute to the performance of public sector organi- zations? \& what is the impact of public entrepreneurship activities on the organizational perfor- mance of the Egyptian Electricity Holding Company, in particular?"}

To answer this major question, the paper examines the following questions:

- What are the exact nature (meaning) of entrepreneurship and the essential activities/ functions of entrepreneurs in general?

- How can entrepreneurship be fostered/ stimulated (requirements)?

- What does the concept of public entrepreneurship mean, in light of the private sector model?

- How does public entrepreneurship affect the performance of state-owned enterprises/ public sector organizations?

- How do public entrepreneurial activities applied at the Egyptian Electricity Holding Company impact its organizational performance, considering the different organizational characteristics?

\section{Research Importance}

Long-neglected by researchers and scholars, entrepreneurship has undergone a dramatic comeback in research over the last few decades. Presently, entrepreneurship is a theme discussed in various disciplines, including management, economics, and small business economics (Elkjær, 2014: 3). Whilst economists and strategists have argued that entrepreneurship plays a crucial role in the efficient functioning of markets, facilitates the development of new technologies, and plays an integral role in the creation of wealth, it is still not clear whether these bold prescriptions hold true in the public sector (Llewellyn, et al.: 35). This emerges as a key area needing more empirical research to evaluate whether high levels of entrepreneurship are associated with improvements in organizational performance of the public sector, putting into consideration the opposing results revealed by literature concerning the entrepreneurship-performance relation.

Also, while some research has explored the nature and effects of public entrepreneurship, a systematic account of the public entrepreneur and the ways in which public-sector entrepreneurship varies from its 
private-sector counterpart is mostly absent in the extant literature (Klein, et al., 2009: 27). Moreover, Despite important research in economics, history, international affairs, and political science focusing on major changes in public interests and public institutions (e.g. Olson, 2000; North, 2005; Guthrie \& Durand, 2008), there is little research on management problems in public entrepreneurship (Klein, et al., 2009: 3).

Hence, this paper seeks to add to the literature of entrepreneurship and to stimulate further research on extending entrepreneurship theory to non-market scope, particularly in developing countries. The study adds to the existing body of knowledge by examining public entrepreneurship in a more detailed and systematic manner, and identifying its impact on organizational performance in light of the current debate. In addition, this study is an attempt in the direction of developing comprehensive research to explain and assess public entrepreneurship conditions and activities existing within public organizations in Egypt.

In other words, the results of this research contribute to a deeper and broader understanding of entrepreneurship in the public sector and its possibilities in environments suffering turbulence and change. Also, the proposed framework here provides a starting point for researchers and practitioners to further examine public entrepreneurship policies and practices. For researchers, the framework clarifies the determining attributes and requirements of entrepreneurship and its relation to the performance of public organizations. For practitioners, the framework illustrates how government performance can be enhanced through improving conditions and applying principles of entrepreneurship, especially in Egypt.

\section{Research Objectives}

Entrepreneurship affects all organizations regardless of size or age, whether they are considered private or public bodies, and independently of their objectives. Its importance to the economy is reflected in its visible growth as a subject of interest for press and in scientific literature. For this reason, it is a matter of interest to academics, businessmen, and governments all over the world (Cuervo, et al.: 5).

In a competitive system of public service provision, government has to unlock new markets with new products and market combinations. Public entrepreneurship is a basic element of the necessary invention and renovation in strategic management of government bureaucracies. Public entrepreneurship originally is introduced by David Osborne and Ted Gaebler, as a fundamental device to reinvent government (Mierlo, 2002: 2).

Even though the study of entrepreneurship has received extensive attention in the literature of business management lately, some difficulties arise when defining the concept. No comprehensive theory exists to explain entrepreneurship in the private market. It follows that a theory of public entrepreneurship will definitely be complicated, drawing on work from a variety of contexts, perspectives, and disciplines. No sustained effort is made to clarify the degree to which entrepreneurship in the public sector is truly analogous to entrepreneurship in the private sector as well (Fernando, 2005: 3-4).

In this paper, the concept of public entrepreneurship is elaborated. The paper addresses and explains the correlation between entrepreneurship and performance in public sector organizations and its essential requirements. In addition to suggesting how public entrepreneurship can benefit by the approaches derived from the private sector in this regard, especially in Egypt.

The main objectives of this research are as follows:

- Exploring and defining the concept of entrepreneurship and distinguishing its various functions. 
- Clarifying the mechanisms and supporting conditions that stimulate entrepreneurship.

- Shedding light on entrepreneurship in public sector and analyzing its relation to the private entrepreneurial practices.

- Identifying the role of public entrepreneurship in enhancing the performance of government institutions, considering the divergent arguments in this respect.

- Measuring and assessing the entrepreneurial practices of the Egyptian Electricity Holding Company, and providing insights and knowledge to its managers and other similar state-owned enterprises whether in Egypt or in other developing countries, in applying the concept of public entrepreneurship and promoting its impact on the organizational performance generally.

\section{Conceptual Framework}

The context of the research conceptual model, as shown in figure (1), has placed an importance in the role of public entrepreneurship in developing the performance of government bureaucratic organizations.

Even if entrepreneurship can have several characteristic dimensions, this paper focuses only on the most evident entrepreneurial functions/ activities/ actions. In agreement with (Carree \& Thurik, 2002; United Nations, 2004; Klein, et al., 2009), entrepreneurship activities are composed of three namely; innovativeness, opportunity seeking, and risk taking. Knowing that, in this paper entrepreneurship activities measure the entrepreneurial posture or positioning of an organization.

Also, in agreement with (Antoncic \& Scarlat, 2005; Mokaya, 2012; La Nafie, et al., 2014), there are two aspects of organizational performance; including financial performance (measured by revenue generation = growth and profitability), and non-financial performance (measured by employee commitment and customer satisfaction).

Finally, in agreement with (Kuratko, et al., 2004; Rutherford \& Holt, 2007), the impact of entrepreneurship on organizational performance depends on some intermediate factors; such as organizational structure, organizational culture, work discretion, top management support, resources availability, reward system, and external environment.

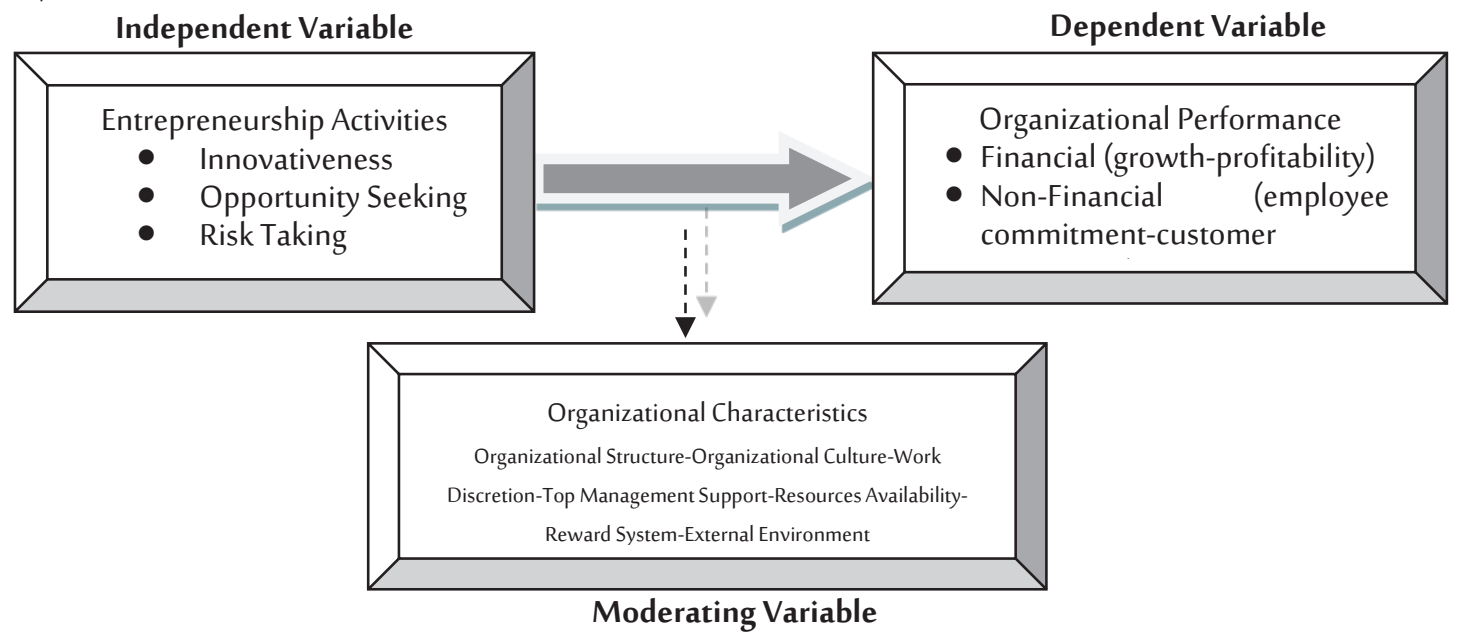

Source: Prepared by the researcher depending on previous references, as mentioned above.

Figure (1) Research Conceptual Model 


\section{Research Methodology}

\section{Research Design}

The design of this study is both descriptive in the theoretical part and quantitative in the applied one. The researcher adopted an analytical approach to define the main concepts and determine the relationship between variables, theoretically, whilst she used an empirical study to investigate the correlations, in practice.

Therefore, in addition to providing a brief overview of relevant literature, a field/ sample survey was used to identify behaviors and attitudes (the orientation) of the Egyptian Electricity Holding Company's executives/ managers/ entrepreneurs (managerial-level bureaucrats) towards adopting entrepreneurial actions and activities, and to capture the recent entrepreneurship conditions and initiatives and their consequences on the performance of this organization. This company was determined as the case study here, as it is one of the crucial public service institutions in Egypt that has succeeded, to some extent, in eliminating most of the critical problems facing it, particularly during the last five years. Also, the directors and executives were chosen as respondents, since they have the knowledge, ability, and accuracy of response.

In order to achieve the objectives of the empirical study, the research set out two main hypotheses as follows:

- H01: "There is no significant impact at significance level $\alpha=0.05$ of the different entrepreneurship activities (innovativeness - opportunity seeking - risk taking) on organizational performance of the Egyptian Electricity Holding Company in terms of financial and non-financial performance."

- H02: "There is no significant impact at significance level $\alpha=0.05$ of entrepreneurship activities on organizational performance of the Egyptian Electricity Holding Company, putting into consideration the different organizational characteristics (organizational structure - organizational culture - work discretion - top management support - resources availability - reward system - external environment)."

\section{Population, Sample, and Selection of the Sample:}

The field/ sample survey was conducted during the first two weeks of September 2016. The whole population was around (180) person who perform as managers at the Egyptian Electricity Holding Company (main premises). A convenient and manageable sample size of (66) person were examined. This sample was randomly selected. Knowing that (90) person (50\% of the population) were sampled and (66) person only responded, thus the response rate was (73.3\%).

\section{Data Collection:}

Primary data was required to identify and examine entrepreneurship practices and performance at the Egyptian Electricity Holding Company. For this purpose, an adopted Arabic-language structured questionnaire was applied as the data collection instrument in this research, since Arabic is the official language in Egypt (the questionnaire was initially formulated in English and then translated).

The study utilized the questionnaire to collect the required primary data using a 5-point Likert scale as the measurement tool, ranging from $1=$ strongly disagree to $5=$ strongly agree (is that $2=$ disagree, $3=$ neutral, 4=agree), in order to measure the respondents' attitudes. 
The questionnaire encompasses ( 24 items) representing the various aspects of subjects to measure determinants of entrepreneurial activities implemented by executives within the bureaucracy, in addition to the dimensions of organizational performance and the other intermediate factors. Thus, the questionnaire was designed and organized into the following sections; demographic profile and professional characteristics of respondents (5 questions not included in the 24 main items), then dimensions of entrepreneurship (independent variable) consist of innovativeness ( 3 items), opportunity seeking ( 3 items), and risk taking (3 items), while performance factors (dependent variable) contain the measurement of financial performance (4 items), and non-financial performance (4 items), and eventually the organizational characteristics (moderating variable) include seven aspects (7 items - one per each).

Knowing that prior to the actual distribution of questionnaires, a pre-test was conducted on 10 respondents to analyze the reliability and validity of the proposed questionnaire. Based on the comments and feedback of the pre-test and some management academic professors as well, amendments were made to the questionnaire for improvement.

\section{Reliability and Validity Test:}

For reliability of the variables, Cronbach's Alpha test was used to evaluate the stability of the questionnaire and reliability of the measures. Accordingly, Cronbach's Alpha was calculated for each variable in this research, as shown in table (1) below.

Table No. (1) Cronbach's Alpha Coefficient of the Research Variables

\begin{tabular}{cc}
\hline Variable & Cronbach's Alpha Coefficient $\left({ }^{*}\right)$ \\
\hline Entrepreneurship Activities & 0.959 \\
\hline Organizational Characteristics & 0.915 \\
\hline Organizational Performance & 0.911 \\
\hline
\end{tabular}

$\left(^{*}\right)$ Note that an alpha level of 0.70 or above is generally considered to be acceptable.

From the table above, it is noticed that all coefficients are near to 1 , so there is evidence that the variables of the study seem to be stable, reliable, and valid. This makes the following results can be taken into consideration.

\section{Methods of Statistical Analysis:}

Statistical Package for Social Survey (SPSS V.18) was the tool for compiling and processing data. Several statistical tools were employed for data analysis in the quantitative part of this research as follows:

- Description of data and indicators.

- Multiple linear regression: To test whether there is a significant effect of some independent variables on the dependent variable and the level and direction of this effect. The effect is considered to be significant if $\mathrm{p}$-value is less than $5 \%$. Whilst the level is determined according to its value, and concerning the direction; if it is positive the relation will be extrusive and if it is negative the relation will be reverse.

- Spearman correlation coefficient: To test the direction and correlation strength between two or- 
dinal variables. If the coefficient is positive the relation will be extrusive and if it is negative the relation will be reverse. While the strength is determined according to its value.

\section{Literature Review: Concepts and Relationships}

\section{Entrepreneurship:}

Since the 1980s, entrepreneurship has appeared as a topic of growing interest amongst management scholars and social scientists. In contrast, historical research on entrepreneurship started much earlier, and it has been predominately concerned with recognizing the process of structural change and development within economies (Jones \& Wadhwani, 2006: 3).

Entrepreneurship is not synonymous with small business (Lumpkin and Dess, 1996: 138). Although entrepreneurship is related to both Small and Medium-sized Enterprises (SMEs) (Elkjær, 2014: 4), since new venture creation focuses on how young and small firms are started up, evolve, and grow. However, entrepreneurship is not restricted to people initiating or operating an innovative small firm. Enterprising individuals in large firms - the so-called intrapreneurs or corporate entrepreneurs - undertake entrepreneurial actions and behaviors as well. Thus, entrepreneurship is related also to institutional change and innovation processes of large and more established organizations (Hernandez, 2010: 40; Carree \& Thurik, 2002: 5).

Whilst sixteenth century definitions characterized entrepreneurship as "an act through which captains of fortune hire mercenary soldiers to conserve small towns" (Martinelli, 1994), contemporary discourses have tended to draw upon economic theories to define entrepreneurship as "an act of new entry" driven by the profit motive (Lumpkin \& Dess, 1996). This can mean: 1) entering new or existing markets with new or existing goods and services, or 2) launching a new venture either through the creation of an entirely new organizational form or through the adaptation of an existing one (Llewellyn, et al.: 4). Therefore, the discipline of entrepreneurship generally studies the how, when, and why of opportunity creation, realization, and utilization for providing goods and services through the introduction of new firms, and within existing ones for both profit and non-profit aims (Naude, et al., 2011: 1). Moreover, it is often assumed that entrepreneurship contributes to value or wealth creation at both the firm-level and the economy-wide level, as (Davidsson, et al., 2006: 27) stated that entrepreneurship is "the creation of new economic activity".

Actually the scientific discussion on entrepreneurship was started by Schumpeter in 1942, noting that the mission of an entrepreneur is to reform production processes by utilizing technological possibilities not tested before, as a result new goods will be produced or goods that are already existed will be produced in a novel and unprecedented way (Acs, et al., 2009: 9-10). Thereby, Schumpeter defines entrepreneurship as "making new combinations which may include the introduction of new goods, new methods of production, opening of new markets, new sources of supply, or new organizations" (Hernandez, 2010: 40). While Fukugawa describes entrepreneurship to mean "the recognition or creation of business opportunities and exploitation of opportunities through new firm creation" (Obaji \& Olugu, 2014: 109-110). Also the definition proposed by (Shane, 2007: 4) requires attention, due to the fact that it considers entrepreneurship as "an activity that involves the detection, evaluation, and exploitation of opportunities to provide new goods and services, ways of organizing, processes, markets, or raw materials through organizing efforts that previously had not existed". 
Thus, there is no universally-accepted definition of entrepreneurship. There seems to be agreement, however, that entrepreneurship includes the creation and invention of something new. In this context, Peter Drucker defines an entrepreneur as "a one who always looks for change, responds to it, and makes use of it as an opportunity". Innovation is the basal tool of entrepreneurs; the means by which they take advantage of change as an opportunity. According to Max Weber; entrepreneurs are "products of particular social condition in which they are brought up, and it is the society which shapes individuals as entrepreneurs" (Havinal, 2009: 97). David Osborne and Ted Gaebler identify the entrepreneur as "one who uses resources in new ways to maximize productivity and effectiveness". In this view, entrepreneurs are those who lead to success in their organizations (Lucy \& Were, 2014: 351). In sum, entrepreneurship as a term is used to describe the role of entrepreneurs as change agents in general. In order to play this role, entrepreneurs need to possess some core competencies like innovativeness, perceiving opportunities, persistence, information gathering, concern for quality, planning, problem solving, etc. (Havinal, 2009: 112).

One relevant concept is "corporate entrepreneurship" (sometimes referred to as intrapreneurship), which is defined as "a process by which individuals inside organizations seek opportunities without regard to resources they currently control" (Mokaya, 2012: 134). Corporate entrepreneurship refers not only to the creation of new business ventures, but also to other innovative activities and orientations, such as the development of new products, goods and services, technologies, administrative techniques and strategies, and competitive postures (Antoncic \& Zorn, 2004: 6). Another relevant concept is "entrepreneurial organization", which means "concepts, skills, and mindset associated with operating large corporations with greater flexibility, responsiveness, and innovation". A third concept here is "entrepreneurial management", which is defined as "a mode of management that is proactive, opportunity-driven, and action-oriented". An entrepreneurial management attempts to establish and balance the innovation capabilities of the organization with the efficient and effective use of resources (Hortovanyi, 2012: 54).

Sternberg and Wennekers (2005) distinguish between the occupational and behavioral notions of entrepreneurship. The occupational notion concentrates on individuals owning and managing businesses for their own account and risk, and it is usually denoted as self-employment, business ownership, or independent entrepreneurship. The behavioral notion centers on actions related to pursuing an entrepreneurial opportunity, and it is generally referred to as entrepreneurial behavior, or simply as entrepreneurship (Wennekers, et al., 2009: 6; Shrivastava \& Shrivastava, 2013: 1). It is clear that the occupational and behavioral notions are not mutually exclusive. A synthesis definition is offered by Gries and Naude (2011) that combines occupational and behavioral views. This definition reflects, to an extent, some of the evolution in the scholarly thinking about entrepreneurship, and defines it as "the resource, process, and state of being through and in which individuals can utilize favorable opportunities in the market by creating and developing new business firms" (Naude, 2013: 7).

Although, historically, entrepreneurship has been reduced to characteristics of the entrepreneurs, trying to identify personality features and cognitive abilities to distinguish entrepreneurs from other people (Hernandez, 2010: 41), Piecuch (2010) notices that; "entrepreneurship can be understood in different ways, as a personal attitude, way of acting, and a process". Entrepreneurship as an attitude refers to the possession of certain personal traits, character, and knowledge, which has a specific meaning in the case of intellectual entrepreneurs. Entrepreneurship as a way of acting means a particular type of activities and behaviors that 
encompass the ability to utilize the ideas or occasions ignored by others - the core of this paper. Entrepreneurship as a process is described as subsequent phases related to the exploitation of an innovative idea (Skica, et al., 2013: 3).

For all those reasons, entrepreneurship is considered an elusive concept. It has been a subject of much debate and is defined differently by various authors. Furthermore, throughout intellectual history the entrepreneur has worn many faces and fulfilled many roles (e.g. Fernando, 2005; Havinal, 2009; Obaji \& Olugu, 2014). The study can focus here on three of the most frequently-mentioned functional roles of entrepreneurs (entrepreneurial functions/ activities), which are associated with major schools of thought on entrepreneurship emphasized by Schumpeter (1934), Kirzner (1973), and Knight (1921), respectively (Carree \& Thurik, 2002: 8; United Nations, 2004: 3-4; Klein, et al., 2009: 5-6):

- Innovativeness: A first is the role of innovator. Schumpeter was the economist who has most prominently drawn attention to the innovating entrepreneur who accelerates the generation, dissemination, and application of innovative ideas.

- Opportunity seeking: A second is the role of perceiving and seizing new profit opportunities. This role is labeled as Kirznerian entrepreneurship.

- Risk taking: A third is the role of assuming and getting ready to take the risk associated with uncertainty. This role is labeled as Knightian entrepreneurship.

Finally, it might be a mistake to assume that the individuals' propensity to behave in an entrepreneurial manner will remain the same over time. Not only may individual motives change, but also the adoption of entrepreneurial modes of behavior and attitude - what has been called entrepreneurial orientation (Llewellyn, et al.: 33).

\section{How to Foster Entrepreneurship (Supporting Conditions):}

According to the Organization for Economic Cooperation and Development (OECD); high levels of entrepreneurship exist but they are mostly not original and informal, which explains the high failure rates in the early stages of businesses, as demonstrated by the Global Entrepreneurship Monitor (GEM) studies (Vicens \& Grullon, 2011: 4). Hence, policy makers face the question of how to create framework conditions conducive to entrepreneurship.

In general, it is self-evident that economic, institutional, and cultural framework conditions have impacts on entrepreneurial activities. A recent OECD study distinguishes between economic fundamentals (macroeconomic stability, labor markets, local infrastructure, tax levels, etc.), that affect the economic activity, and policy domains that directly influence entrepreneurship. The study identifies three policy issues significant for entrepreneurial initiatives, which are access to finance, ease of entry and exit from market, and government support schemes (United Nations, 2004: 11-12).

Furthermore, Baumol $(1988,1990)$ provides a causal explanation for how institutions affect entrepreneurship. He argues that inherited institutions matter because they generate incentives that allocate entrepreneurship between productive activities such as innovation, and unproductive ones as organized crime. Recent historical research has explored the precise mechanisms by which institutions affect productivity 
and long-term growth. For instance, Maurer (2002) explores how the existence of an undemocratic authoritarian political system and selective enforcement of property rights shaped the Mexican financial system and constrained entrepreneurship opportunities in late nineteenth century. Historical studies have also looked more closely at the impact of patent rights and the law of business corporations to examine their influence on entrepreneurial activity and behavior (e.g. Khan, 2005) (Jones \& Wadhwani, 2006: 17-18). As well, the study of (Naude, et al., 2011: 5) identifies the importance of educational and capability-building policies as key public policies that can play a complementary role in fostering entrepreneurial innovation.

Other authors have linked structural and organizational characteristics of firms to the level of entrepreneurship. For example, Bridges, et al. (1968) found increased hierarchy causes and leads to low levels of product entrepreneurship through expanding communication burdens. Similarly, Hall (1996) found high levels of formalization, such as rigid work procedures and job descriptions, are associated with low levels of entrepreneurship through imposing limits and restrictions upon innovative behaviors. In a broader study, Moon (1999) found cultural factors, such as values and ethics, may significantly impact upon the entrepreneurial activities of organizations (Llewellyn, et al.: 6). Additionally, many research indicated that strong internal organizational support is important for entrepreneurship, including top management support, organizational structure, training, reward system, and resources availability (Westrup, 2013: 98; Antoncic \& Zorn, 2004: 5; Shamsuddin, et al., 2012: 111).

On the other hand, the importance of the individual level illustrates that policies for boosting entrepreneurial capacity should not focus solely on macroeconomic conditions and access to finance; the most frequently-used policy tools to promote and reinforce entrepreneurship. Rather, the establishment and development of firms count, to a large extent, on the skills and competencies of the individual entrepreneur. Therefore, a substantial complementary approach to foster and sustain entrepreneurship is strengthening individuals' entrepreneurial traits. One of the most important theoretical foundations for this approach is the studies of McClelland (1961). McClelland confirms the importance of the motivational aspect of the entrepreneur. He identifies ten personal qualities/ attributes for strengthening entrepreneurial potential; opportunity seeking, risk taking, demand for efficiency and quality, commitment to the work contract, information gathering, goal setting, systematic planning and monitoring, persistence, persuasion and networking, and self-confidence and independence (United Nations, 2004: 9-10).

\section{Entrepreneurship in the Public Sector (Public Entrepreneurship) and Its Relation to Pri- vate Entrepreneurial Practices:}

As Holcombe notes; "if political goals are not implemented in the least-cost way, then there is a profit opportunity from restructuring the government activity, so that goals are achieved at lower costs" (Klein, et al., 2009: 10). The importance of entrepreneurship and entrepreneurial management in the public sector has become an area of growing interest. Since the 1990s, expectations for public sector to be more effective and innovatively-oriented have increased. Some believe that the public sector could benefit greatly from the innovative approaches and activities of the private sector (Tosterud: 3). Although innovation has generally been defined as "the development and/or the use of new ideas or behaviors resulting in a new outcome for an organization", innovation in public sector may not necessarily be associated with invention or 
creation of new services and products. Thus, innovation in public sector may range from the development of new services and programs, to the improvement of managerial processes and institutional tasks through re-conceptualizing existing resources (Lucy \& Were, 2014: 351).

In general, the public sector operates in circumstances that differ fundamentally from those of the private sector, in areas such as objectives, obligations, financing, and environment (Westrup, 2013: 98). For example, whilst the entrepreneurial firm typically has well-defined objectives, can rely on market signals of success (economic profit) and failure (economic loss), and must overcome a competitive selection process to persist as a going concern, public actors have more complex objectives, may not have access to obvious signals of performance, and may persevere for reasons other than shareholder wealth and customer satisfaction. In spite of all these differences, entrepreneurial concepts still make sense in the context of public action (Klein, et al., 2009: 6).

In a book that attracted world-wide attention, David Osborne and Ted Gaebler (1992) develop an extensive argument for a complete transformation of bureaucratic government into entrepreneurial one. In their view, government should be reinvented, not abolished (Mierlo, 2002: 7). The form of entrepreneurial government is introduced as a means to market-oriented practices for better services, is that the adoption of some helpful and profitable entrepreneurial practices in the public sector could be a sound approach for satisfying citizens' needs for more innovative, responsive, efficient, and lower-cost government.

Despite the widespread belief in the applicability of entrepreneurial activities to public organizations, there is still an ongoing debate about their convenience to the public sector in terms of its core values, such as democracy and accountability, and under the existing structural and legal restrictions on public managerial behaviors broadly. Actually the main idea behind public entrepreneurship is not to make the government more businesslike. Rather, the point is to increase opportunities to take and capitalize challengeable ideas, and to find ways to offer more public choices and benefits to citizens (Lucy \& Were, 2014: 346-347).

Hence, public or bureaucratic entrepreneurship differs from entrepreneurship in commercial private enterprises (Mierlo, 2002: 12). Kearney, et al. (2009) compare between entrepreneurship in public and private organizations, defining public sector entrepreneurship as "the process within the public sector organization that results in innovative activities, such as the development of new and existing services, technologies, administrative techniques, or new improved strategies, risk taking, and proactivity". Those authors also propose that entrepreneurship produces superior organizational performance within public sector (Matthews: 2). (Currie, et al., 2008: 987) describe a public entrepreneur as "the one who identifies market opportunities within the political landscape, optimizes the performance-enhancing potential of innovation for the public sector organization, and carries stakeholders in a way that permits risk and recognizes the stewardship of public resources as well".

Another parallel concept here is "social entrepreneurship", as (Llewellyn, et al.: 19) consider it "entrepreneurship but with the primary objective of generating social benefits received by the society". Social entrepreneurship then is an attempt to draw upon business methods and techniques to find solutions to the rising social problems facing countries worldwide, especially developing countries. In fact social entrepreneurship was created to simulate the business entrepreneurial sector in its competitiveness, effectiveness, efficiency, and best use of resources (Sherif \& Aaref, 2015: 2-3). Some researchers (e.g. Pascual, et al., 2011) 
approach it as "sustainable entrepreneurship", which aims to solve environmental and social problems by applying business principles. So sustainability entrepreneurs are "those who use entrepreneurial values and methods to solve major sustainability problems". Sustainability entrepreneurs usually apply imagination to challenging problems to conceive, prototype, and create solutions that achieve environmental, social, and economic value. Knowing that this was considered here when the researcher chose the case study of the Egyptian Electricity Holding Company, for its role and serious attempts in solving the critical societal problem of electricity in Egypt and providing sustainable electrical energy.

On the other hand, it is worth to be mentioned that most of the political entrepreneurship literature takes a Schumpeterian perspective combined with the Kirznerian one, focusing on creative political innovations, which rely mainly on windows of opportunity for adjusting the way that public institutions operate. Besides, under the Knightian conceptualization of entrepreneurship the greatest economic returns are achieved by those who bear market uncertainties successfully. In public entrepreneurship, these ideas can be translated into the view that innovation requires taking risks and making investments under uncertainty, which may call for the establishment of new public organizations (e.g. regulatory bodies). Note that sometimes this can involve some kind of experimentation, failure, and learning (Klein, et al., 2009: 8-9).

In addition, an analytical distinction can be made between two levels of public entrepreneurship; the level of public organization (institutional) and the level of public official (individual). At the first level, the bureaucratic organization of government has to be transformed into a more entrepreneurial one. At the second level, the bureaucratic official within the government entities has to be changed to a more entrepreneurial one (Mierlo, 2002: 7). In relation to public entrepreneurs, Robert and King (1996) discuss a typology of public entrepreneurship. These are the following (Fernando, 2005: 4-5):

- Political entrepreneurs: Elected public officials.

- Executive entrepreneurs: Top-level appointed officials who head governmental agencies (the core here in this research).

- Bureaucratic entrepreneurs: Innovative agency staffers who develop creative ideas.

- Policy entrepreneurs: Officials working outside the formal boundaries of government who initiate policy change.

Moreover, the public sector has got to work under some barriers and obstacles which hamper its performance in the adoption of entrepreneurship, especially in the developing countries. These are broken down into three categories, as mentioned by (Llewellyn, et al.: 28); the structure, culture, and external environment. Organizational structure is seen as restraining entrepreneurial activity, particularly protectionist hierarchies, inappropriate job designs, and departmentalism. However, some other barriers are seen as being cultural. This category includes lack of trust between managerial groups, breaking the mindset of officers, moving from risk-adverse cultures, and removing organizational complacency. Finally, comes the external pressure in the form of restrictive regulatory frameworks, over-lawyered administrative systems, and political obstacles.

Therefore, creating an entrepreneurial organization in the government is a high-challenging task, particularly in those developing countries. Public institutions may pursue a variety of entrepreneurial management strategies for this purpose, such as finding and hiring workers who demonstrate entrepreneur- 
ial behaviors, an entrepreneurial employee continuous training track, monetary and other non-monetary compensation, communicating the agency's mission and vision, and above all a fun, learning, creative, and safe place to work at and take risks. In other words, the successful entrepreneurial organization should demonstrate a fit between the employee and the employing agency (Tosterud: 3-5).

\section{Public Entrepreneurship and Organizational Performance:}

Business environment has become highly dynamic, unpredictable, and competitive. This is aided by globalization, trade liberalization, and technological developments, particularly in the area of ICTs. All these developments have made the world a global market where organizations compete beyond national boundaries. Considering these scenarios, it becomes imperative for organizations, irrespective of their nature and size, to exhibit entrepreneurial behavior and boost supportive organizational culture and characteristics in order to survive, prosper, gain competitive advantages, and achieve superior performance (Otache $\&$ Mahmood, 2015: 524).

With the goal of performing government tasks effectively and achieving superior public performance, a number of market-based approaches have been introduced into the public sector. Unlike privatization and contracting out, which reduce public sector involvement and responsibility as a significant service provider, public entrepreneurship offers great many advantages and has important roles to play in governments. Thus, adopting entrepreneurial practices can improve the in-house capacities for contributing to the public values of sustainability and productivity, and could be the best avenue to resolve recurrent perceptions of low performance and less-efficient services (Lucy \& Were, 2014: 347). On the other hand, this suggests a dilemma; "entrepreneurship may be necessary to develop the performance of public sector organizations but the cost of innovation failure is oftentimes too high" (Tosterud: 3). For that reason, there is a need to determine precisely the role of public entrepreneurship and to measure its impact on the performance of public organizations in reality, which is the aim of this study.

According to (Carree \& Thurik, 2002: 4); entrepreneurship is an ill-defined, multidimensional concept. The difficulties in identifying and measuring the standard of entrepreneurial activities complicate the measurement and evaluation of their influence on organizational performance, particularly in the public sector. So, comprehending their role in performance requires an overall framework because there are various intermediate variables or determinants to explain how entrepreneurship affects performance. Knowing that measuring the performance of public sector through private sector tools and principles is hardly a new or a recent idea. This is broadly representing the view that the current relationship between public and private sectors is about transferring methods and practices from one sector to the other (Adcroft \& Willis: 4).

Organizational performance in general is "an indicator of the level of accomplishment that reflects the success of the manager/ entrepreneur". Performance of the organization is the desired outcome of the organizational behavior of the people within it. Assessment of organizational performance can be perceived from the financial perspective (La Nafie, et al., 2014: 86). Financial performance demonstrates the ability of the company to generate new resources from daily operations in a particular period. (Otache \& Mahmood, 2015: 528) argue that financial performance measurement could be in terms of profitability, market share, 
growth, or overall business performance. However, the measurement of non-financial performance is also important for organizations, especially the public ones, to know how far are the human aspect, the aspect of customers, and other organizational aspects of the work.

Entrepreneurship has been of interest to scholars and practitioners due to its beneficial effect on organizational performance. There is adequate empirical evidence that entrepreneurship is closely linked to improved firm performance (e.g. Pinchot, 1985; Holt, 1992; Herbert \& Brazeal, 1999; Lindsey, 2001; Drejer, et al., 2004; Zhang \& Zhang, 2012). The quest for improved performance of organizations operating in a dynamic and competitive environment now can no longer be found simply in lower costs or higher quality only. Besides, it lies in flexibility, adaptability, responsiveness, aggressiveness, proactiveness, and innovativeness; all dimensions of entrepreneurship. Therefore, firms with high entrepreneurial intensity usually experience better performance (Mokaya, 2012: 133-134). As corporate entrepreneurship (entrepreneurship within an existing organization or an organizational-level entrepreneurship) is considered an essential predictor of economic and organizational development, performance, and wealth creation (Antoncic \& Zorn, 2004: 5).

Hence, the relationship between corporate entrepreneurship and organizational performance has been considerably researched, despite the focus was mainly on the private business organizations. Scholars have postulated that entrepreneurship leads to superior organizational performance. Nevertheless, a critical review of the extant literature reveals that the findings are inconclusive (Rauch, et al., 2009; Karacaoglu, et al., 2012). On the one hand, some studies have affirmed a positive relationship between entrepreneurship and organizational performance (e.g. Antoncic \& Scarlat, 2005; Mokaya, 2012). On the other hand, other studies have confirmed a negative relationship (e.g. George, et al., 2001; Shamsuddin, et al., 2012), or the insignificant impact of entrepreneurship on organizational performance (e.g. Wiklund \& Shepherd, 2005; Kolakovick, 2006). Also, there are divergent arguments regarding the effect of entrepreneurship on organizational performance. Some researchers have posited that the influence of entrepreneurship on organizational performance is based on a multiplicity of different factors, such as organizational structure, organizational culture, work discretion, top management support, organizational resources availability, reward system, and external environment (e.g. Kuratko, et al., 2004; Rutherford \& Holt, 2007). However, another research has shown that there is no significant relationship between several organizational internal factors, particularly resources availability and organizational structure, and entrepreneurship (e.g. Hough \& Gerlach, 2008). More so, some other scholars have observed that continuous engagement in entrepreneurial activities does not guarantee ongoing superior performance, especially in emerging economies, for the lack of organizational formalization, institutional support, and experienced managers (e.g. Tang, et al., 2008; Tang \& Tang, 2010) (Otache \& Mahmood, 2015: 524-525; La Nafie, et al., 2014: 83-84). This means that entrepreneurship-performance relationship, especially in the public sector, needs to be further investigated, thus the current research is conducted.

In this respect, (Lumpkin \& Dess, 1996; Wiklund, 1999) contend that organizational performance is generally multi-dimensional in nature and that suitable measures should contain both growth and financial performance indicators. Therefore, growth and profitability levels are performance elements that could 
be considered remarkable consequences of entrepreneurship (Antoncic \& Scarlat, 2005: 72; Antoncic \& Zorn, 2004: 6; Shamsuddin, et al., 2012: 120). Wiklund (1999) suggests that sales growth has high generality and is a convenient measure of growth, given that sales growth also reflects increased demand for the company's products and services. But as Zahra (1991) notes; "growth itself is not sufficient to measure organizational performance, as in some cases the company might choose to trade-off long-term growth for short-term profitability" (Mokaya, 2012: 138-139). At the same time, Kolakovic, et al. (2008) for instance, reveal the absence of a strong link between the company's entrepreneurial intensity and profitability itself (Shamsuddin, et al., 2012: 117). Accordingly, the researcher here suggests that measures of both growth and profitability can provide a better indication of overall organizational financial performance, putting into consideration that adapting these concepts to fit the nature of public organizations is necessary in our study; that means the interpretation of the measures and translation of these principles into a public sector context. For example, measuring the revenue generation in the state-owned enterprises through indicators most probably like providing more/ better products and services at the same cost or providing the same products and services in lower costs; likely it is more about understanding the relationship between economic inputs and outputs.

Thereby, in previous research many studies used financial performance indicators as a result of entrepreneurship activities and orientations. Since the most common financial performance measurement, especially in the study of entrepreneurship, is generating revenue through growth and profitability, as mentioned above. While this paper is attempting to provide evidence that non-financial factors are also major indicators for the outcome of entrepreneurship, which is confirmed by some research (e.g. Bulut \& Yilmaz, 2008; Chen \& Cangahuala, 2010; Arfaei, et al., 2012; La Nafie, et al., 2014). Non-financial performance measurement in this paper, that is the most important in public sector generally, focuses on employee commitment and customer satisfaction. According to Holt, et al. (2007); the behavior of entrepreneurship associates with high job satisfaction and commitment in the workplace. In addition, Arfaei, et al. (2012) research concludes that there is a positive relationship between entrepreneurship and customer satisfaction, which depends a lot on the quality of products and services (La Nafie, et al., 2014: 88-89).

\section{Application: Empirical Study}

A field/ sample survey was used to identify the attitudes of the Egyptian Electricity Holding Company's executives towards adopting entrepreneurship activities and the consequences on performance, in light of the organizational characteristics.

\section{About the Egyptian Electricity Holding Company (Background):}

The Egyptian Electricity Authority was established in 1976 to be responsible for all power plants, transmission, and distribution networks. In 2000, Law 164 was issued to transfer the Egyptian Electricity Authority to the Egyptian Electricity Holding Company and its subsidiaries in the production, transmission, and distribution of electricity (The Egyptian Electricity Holding Company's Official Website, 1/8/2016). 
The Egyptian Electricity Holding Company seeks to achieve the concept of national responsibility in all services and activities. The mission of the company is to provide sustainable electrical energy for all customers through available resources, according to international standards at competitive prices, by corporate effort adopting quality standards, resources utilization, and environment conservation, based on highly-efficient human potentials and technologies, thus it takes into consideration all safeguards for the stability and continuity of electrical nutrition without interruption with the optimal use of resources to maximize profitability. In addition to performing work in an ethically responsible manner for the benefit of all customers, employees, and society (The Egyptian Electricity Holding Company's Official Website, 1/8/2016).

Thereby, it is obvious that the Egyptian Electricity Holding Company adopts entrepreneurship concepts through its endeavors to achieve world class leadership and excellence of sustainable electrical energy.

\section{Sample Characteristics (Demographic and Professional Characteristics of Respondents):}

Table (2) provides some descriptive statistics of the sample to give a general view of the demographic and professional characteristics of respondents.

Table No. (2) Sample Description according to the Basic Characteristics of Respondents

\begin{tabular}{|c|c|c|c|c|c|c|c|c|c|}
\hline Variable & & ader & & Age & & & Edu & cation & \\
\hline Faces & Male & Female & $\begin{array}{c}\text { Under } 35 \\
\text { Years }\end{array}$ & $\begin{array}{c}\text { 35-Less } \\
\text { than } 50 \\
\text { Years }\end{array}$ & $\begin{array}{c}50 \text { Years or } \\
\text { Above }\end{array}$ & $\begin{array}{c}\text { Post } \\
\text { Graduate } \\
\text { Studies }\end{array}$ & B.Sc. & $\begin{array}{c}\text { Less than } \\
\text { B.Sc. }\end{array}$ & Total \\
\hline Number & 65 & 1 & 0 & 35 & 31 & 19 & 47 & 0 & 66 \\
\hline Percentage & $98.5 \%$ & $1.5 \%$ & $0 \%$ & $53 \%$ & $47 \%$ & $28.8 \%$ & $71.2 \%$ & $0 \%$ & $100 \%$ \\
\hline
\end{tabular}

\begin{tabular}{ccccccccc}
\hline Variable & \multicolumn{3}{c}{ Job Title } & \multicolumn{4}{c}{ Work Duration } \\
\hline Faces & $\begin{array}{c}\text { Board } \\
\text { Member }\end{array}$ & Sector Head & $\begin{array}{c}\text { Department } \\
\text { Manager }\end{array}$ & $\begin{array}{c}\text { Less than 10 } \\
\text { Years }\end{array}$ & $\begin{array}{c}\text { 10-Less than } \\
\text { 25 Years }\end{array}$ & $\begin{array}{c}\text { 25 Years or } \\
\text { Above }\end{array}$ & Total \\
\hline Number & 7 & 19 & 40 & 0 & 65 & 1 & 66 \\
\hline Percentage & $10.6 \%$ & $28.8 \%$ & $60.6 \%$ & $0 \%$ & $98.5 \%$ & $1.5 \%$ & $100 \%$ \\
\hline
\end{tabular}

The previous table indicates that the sample consists of $98.5 \%$ males and just one female, and $53 \%$ of the respondents their ages are from 35 to less than 50 years. According to the educational level, $71.2 \%$ have a B.Sc. degree (no one has less than B.Sc.). The majority of $60.6 \%$ of the sample are department managers, and $98.5 \%$ of the respondents spent from 10 to less than 25 years as a work duration at the Egyptian Electricity Holding Company.

\section{Building Indicators of the Research Variables:}

It is important to mention that 14 indicators were already created; by grouping the statements which each indicator consists of, then re-dividing the indicators into 5 categories according to Likert scale. Table (3) below presents the frequencies and percentage of the different faces for each indicator and the number of statements each one implies. 
Table No. (3) Number and Percentage for Different Faces of the Research Indicators according to Likert Scale

\begin{tabular}{|c|c|c|c|c|c|c|c|}
\hline \multirow[b]{2}{*}{ Indicator } & \multirow[b]{2}{*}{$\begin{array}{l}\text { Number of } \\
\text { Statements }\end{array}$} & \multicolumn{6}{|c|}{ Faces } \\
\hline & & & $\begin{array}{l}\text { Strongly } \\
\text { Disagree }\end{array}$ & Disagree & Neutral & Agree & $\begin{array}{c}\text { Strongly } \\
\text { Agree }\end{array}$ \\
\hline \multirow{2}{*}{ Innovativeness } & \multirow{2}{*}{3} & Number & 0 & 14 & 21 & 18 & 13 \\
\hline & & Percentage & $0 \%$ & $21.2 \%$ & $31.8 \%$ & $27.3 \%$ & $19.7 \%$ \\
\hline \multirow{2}{*}{ Opportunity Seeking } & \multirow{2}{*}{3} & Number & 0 & 13 & 27 & 10 & 16 \\
\hline & & Percentage & $0 \%$ & $19.7 \%$ & $40.9 \%$ & $15.2 \%$ & $24.2 \%$ \\
\hline \multirow{2}{*}{ Risk Taking } & \multirow{2}{*}{3} & Number & 7 & 20 & 14 & 16 & 9 \\
\hline & & Percentage & $10.6 \%$ & $30.3 \%$ & $21.2 \%$ & $24.2 \%$ & $13.6 \%$ \\
\hline \multirow{2}{*}{$\begin{array}{l}\text { Entrepreneurship } \\
\text { Activities }\end{array}$} & \multirow{2}{*}{9} & Number & 0 & 13 & 28 & 9 & 16 \\
\hline & & Percentage & $0 \%$ & $19.7 \%$ & $42.4 \%$ & $13.6 \%$ & $24.2 \%$ \\
\hline \multirow{2}{*}{$\begin{array}{l}\text { Organizational } \\
\text { Structure }\end{array}$} & \multirow{2}{*}{1} & Number & 7 & 15 & 28 & 12 & 4 \\
\hline & & Percentage & $10.6 \%$ & $22.7 \%$ & $42.4 \%$ & $18.2 \%$ & $6.1 \%$ \\
\hline \multirow{2}{*}{$\begin{array}{l}\text { Organizational } \\
\text { Culture }\end{array}$} & \multirow{2}{*}{1} & Number & 13 & 15 & 19 & 15 & 4 \\
\hline & & Percentage & $19.7 \%$ & $22.7 \%$ & $28.8 \%$ & $22.7 \%$ & $6.1 \%$ \\
\hline \multirow{2}{*}{ Work Discretion } & \multirow{2}{*}{1} & Number & 17 & 20 & 9 & 15 & 5 \\
\hline & & Percentage & $25.8 \%$ & $30.3 \%$ & $13.6 \%$ & $22.7 \%$ & $7.6 \%$ \\
\hline \multirow{2}{*}{$\begin{array}{l}\text { Top Management } \\
\text { Support }\end{array}$} & \multirow{2}{*}{1} & Number & 18 & 16 & 11 & 16 & 5 \\
\hline & & Percentage & $27.3 \%$ & $24.2 \%$ & $16.7 \%$ & $24.2 \%$ & $7.6 \%$ \\
\hline \multirow{2}{*}{$\begin{array}{l}\text { Resources } \\
\text { Availability }\end{array}$} & \multirow{2}{*}{1} & Number & 23 & 10 & 19 & 9 & 5 \\
\hline & & Percentage & $34.8 \%$ & $15.2 \%$ & $28.8 \%$ & $13.6 \%$ & $7.6 \%$ \\
\hline \multirow{2}{*}{$\begin{array}{l}\text { Reward } \\
\text { System }\end{array}$} & \multirow{2}{*}{1} & Number & 27 & 3 & 21 & 13 & 2 \\
\hline & & Percentage & $40.9 \%$ & $4.5 \%$ & $31.8 \%$ & $19.7 \%$ & $3 \%$ \\
\hline \multirow{2}{*}{$\begin{array}{l}\text { External } \\
\text { Environment }\end{array}$} & \multirow{2}{*}{1} & Number & 38 & 23 & 4 & 0 & 1 \\
\hline & & Percentage & $57.6 \%$ & $34.8 \%$ & $6.1 \%$ & $0 \%$ & $1.5 \%$ \\
\hline \multirow{2}{*}{$\begin{array}{l}\text { Financial } \\
\text { Performance }\end{array}$} & \multirow{2}{*}{4} & Number & 0 & 2 & 19 & 25 & 20 \\
\hline & & Percentage & $0 \%$ & $3 \%$ & $28.8 \%$ & $37.9 \%$ & $30.3 \%$ \\
\hline \multirow{2}{*}{$\begin{array}{l}\text { Non-Financial } \\
\text { Performance }\end{array}$} & \multirow{2}{*}{4} & Number & 7 & 18 & 18 & 11 & 12 \\
\hline & & Percentage & $10.6 \%$ & $27.3 \%$ & $27.3 \%$ & $16.7 \%$ & $18.2 \%$ \\
\hline \multirow{2}{*}{$\begin{array}{l}\text { Organizational } \\
\text { Performance }\end{array}$} & 0 & Number & 0 & 0 & 30 & 23 & 13 \\
\hline & 0 & Percentage & $0 \%$ & $0 \%$ & $45.5 \%$ & $34.8 \%$ & $19.7 \%$ \\
\hline
\end{tabular}

From the previous table, it is clear that there is no specific pattern in the responses of the sample's units. The distribution of the responses differs from one indicator to another, although most of the highest responses are tending generally towards neutral then disagreement, which means that the presence or the level of adopting/ applying the research concepts at the Egyptian Electricity Holding Company in general is around or below average. 
The following two tables (4) and (5) indicate the relation between each general indicator and the sub-variables form it; by using Spearman correlation coefficient to determine which sub-variable has the most influence on the whole indicator. Note that the research did not need to create a general indicator for the organizational characteristics (moderating variable), according to its purposes and as it will be shown later.

\section{Entrepreneurship Activities (Independent Variable):}

Table No. (4) Spearman Coefficient of the Entrepreneurship Activities Sub-Variables

\begin{tabular}{cccc}
\hline Risk Taking & Opportunity Seeking & Innovativeness & Sub-Variable \\
\hline 0.945 & 0.956 & 0.945 & Spearman Coefficient \\
\hline 0.000 & 0.000 & 0.000 & Significance \\
\hline
\end{tabular}

As shown in the previous table, there is a strong positive significant relationship between the entrepreneurial activities indicator and each sub-variable. The effects of innovativeness and risk taking are the same but opportunity seeking is slightly more effective on the entrepreneurial activities than the other two sub-variables, which reflects their influence on this indicator at the Egyptian Electricity Holding Company in general.

\section{Organizational Performance (Dependent Variable):}

Table No. (5) Spearman Coefficient of the Organizational Performance Sub-Variables

\begin{tabular}{ccc}
\hline Sub-Variable & Financial Performance & Non-Financial Performance \\
\hline Spearman Coefficient & 0.943 & 0.936 \\
\hline Significance & 0.000 & 0.000 \\
\hline
\end{tabular}

As shown from the previous table, there is a strong positive significant relationship between the organizational performance indicator and each sub-variable. As well, financial performance affects the organizational performance at the Egyptian Electricity Holding Company more than non-financial performance.

\section{Testing the Research Hypotheses:}

The two hypotheses of this research were tested here using the statistical tools mentioned before. In order to answer the questions of the study and analyze the correlations between variables, multiple linear regressions were used to examine the influence of the different aspects of entrepreneurship activities (innovativeness, opportunity seeking, risk taking) on financial performance and non-financial performance, along with the influence of the entrepreneurial activities on organizational performance, taking into consideration the different organizational characteristics (organizational structure, organizational culture, work discretion, top management support, resources availability, reward system, external environment), as moderating variables. 


\section{First Hypothesis:}

H01: "There is no significant impact at significance level $\boldsymbol{\alpha}=\mathbf{0 . 0 5}$ of the different entrepreneurship activities (innovativeness - opportunity seeking - risk taking) on organizational performance of the Egyptian Electricity Holding Company in terms of financial and non-financial performance."

To show whether the previous hypothesis is acceptable or not, two multiple linear regression models were used to test the influence of the different sides of entrepreneurial activities (innovativeness, opportunity seeking, risk taking) on each of the financial and non-financial performance, as presented in table (6). Knowing that the hypothesis will be rejected if the significance of the model is less than 0.05 , vice versa.

Table No. (6) Multiple Linear Regression Models of the Two Dependent Sub-Variables On the Different Independent Sub-Variables

\begin{tabular}{|c|c|c|c|c|c|c|}
\hline $\begin{array}{l}\text { Multiple Linear } \\
\text { Regression Model }\end{array}$ & $\begin{array}{l}\text { Dependent } \\
\text { Sub-Variable }\end{array}$ & $\begin{array}{c}\text { Independent Sub- } \\
\text { Variables }\end{array}$ & Beta & P-Value & $\begin{array}{l}\text { Adjusted R } \\
\text { Squared }\end{array}$ & $\begin{array}{l}\text { Significance } \\
\text { of the Model }\end{array}$ \\
\hline \multirow{3}{*}{ First Model } & \multirow{3}{*}{$\begin{array}{c}\text { Financial } \\
\text { Performance }\end{array}$} & Innovativeness & 0.794 & 0.000 & \multirow{3}{*}{0.929} & \multirow{3}{*}{0.000} \\
\hline & & Opportunity Seeking & 0.423 & 0.028 & & \\
\hline & & Risk Taking & -0.015 & 0.272 & & \\
\hline \multirow{3}{*}{ Second Model } & \multirow{3}{*}{$\begin{array}{l}\text { Non-Financial } \\
\text { Performance }\end{array}$} & Innovativeness & 0.612 & 0.000 & \multirow{3}{*}{0.887} & \multirow{3}{*}{0.000} \\
\hline & & Opportunity Seeking & -0.027 & 0.885 & & \\
\hline & & Risk Taking & 0.315 & 0.024 & & \\
\hline
\end{tabular}

The table above indicates that:

- The two overall models are significant at the confidence level of $95 \%$, as the $p$-value of both is less than 0.05 .

- For the first model, when financial performance is the dependent variable:

- Innovativeness and opportunity seeking have significant positive effects on financial performance at confidence level $95 \%$ and this appears from the value of beta, but risk taking does not have a significant effect on it as its $p$-value is more than 0.05 .

- From adjusted $\mathrm{R}$ squared, it is noticed that innovativeness and opportunity seeking have the ability to explain about $93 \%$ from the variation in financial performance of the company.

- $\quad$ For the second model, when non-financial performance is the dependent variable:

- Innovativeness and risk taking have significant positive effects on non-financial performance at confidence level $95 \%$ and this appears from the value of beta, whilst opportunity seeking does not have a significant effect on it as its p-value is more than 0.05 .

- From adjusted R squared, it is noticed that innovativeness and risk taking have the ability to explain about $89 \%$ from the variation in non-financial performance.

From the previous results, the study can conclude that there is a significant impact at significance level $\alpha=0.05$ of the different entrepreneurship activities on organizational performance of the Egyptian Electricity Holding Company in terms of financial and non-financial performance, which means that the first hypothesis is rejected. 


\section{Second Hypothesis:}

H02: "There is no significant impact at significance level $\alpha=0.05$ of entrepreneurship activities on organizational performance of the Egyptian Electricity Holding Company, putting into consideration the different organizational characteristics (organizational structure - organizational culture - work discretion - top management support - resources availability - reward system - external environment)."

To prove whether the previous hypothesis is acceptable or not, a multiple linear regression model, presented in table (7), was used to test the influence of the entrepreneurial activities on organizational performance, taking into consideration the different sides of organizational characteristics (organizational structure, organizational culture, work discretion, top management support, resources availability, reward system, external environment), as moderating variables. As mentioned before, the hypothesis will be rejected if the significance of the model is less than 0.05 , vice versa.

Table No. (7) Multiple Linear Regression Model of the Dependent Variable On the Independent Variable Considering the Moderating Sub-Variables

\begin{tabular}{|c|c|c|c|c|c|c|}
\hline \multirow{9}{*}{$\begin{array}{l}\text { Multiple Linear } \\
\text { Regression } \\
\text { Model }\end{array}$} & $\begin{array}{l}\text { Dependent } \\
\text { Variable }\end{array}$ & Independent Variables & Beta & P-Value & $\begin{array}{l}\text { Adjusted R } \\
\text { Squared }\end{array}$ & $\begin{array}{l}\text { Significance } \\
\text { of the Model }\end{array}$ \\
\hline & \multirow{8}{*}{$\begin{array}{c}\text { Organizational } \\
\text { Performance }\end{array}$} & Entrepreneurship Activities & 0.016 & 0.000 & \multirow{8}{*}{0.980} & \multirow{8}{*}{0.000} \\
\hline & & Organizational Structure & 0.018 & 0.280 & & \\
\hline & & Organizational Culture & -0.036 & 0.101 & & \\
\hline & & Work Discretion & 0.089 & 0.000 & & \\
\hline & & Top Management Support & -0.050 & 0.016 & & \\
\hline & & Resources Availability & 0.025 & 0.154 & & \\
\hline & & Reward System & -0.049 & 0.005 & & \\
\hline & & External Environment & 0.050 & 0.000 & & \\
\hline
\end{tabular}

The table above clarifies that:

- When entering the different sides of organizational characteristics as moderating variables:

- The overall model is significant at the confidence level of $95 \%$, as the p-value is less than 0.05 .

- Entrepreneurial activities still have a significant positive effect on organizational performance at confidence level $95 \%$, and this appears from the value of beta.

- Work discretion and external environment have significant positive effects on organizational performance, while top management support and reward system have significant negative effects on organizational performance at confidence level $95 \%$, and this appears from the value of beta, however the other internal factors do not affect the significance of entrepreneurial activities on organizational performance in general.

- From adjusted $\mathrm{R}$ squared, it is noticed that entrepreneurial activities have the ability to explain about $98 \%$ from the variation in organizational performance of the company, taking into consideration work discretion, top management support, reward system, and external environment. 
From the previous results, the research can conclude that there is a significant impact at significance level $\alpha=0.05$ of entrepreneurship activities on organizational performance of the Egyptian Electricity Holding Company, putting into consideration some organizational characteristics, so that the second hypothesis is also rejected.

\section{Conclusion: Concluding Remarks}

This paper provides several contributions to the literature in the field of entrepreneurship in public sector. Thus, it adds to the existing body of knowledge by examining public entrepreneurship in a more detailed, comprehensive, and systematic manner. It identifies a framework for analyzing public entrepreneurship and its relation to private entrepreneurial activities and behaviors. It also confirms the research conducted on the importance of entrepreneurship to the government performance, particularly in the developing countries, as an essential management tool and a fundamental performance improvement strategy. Besides, it offers initial support for expanding public entrepreneurship research using a more integrative approach to include many variables in the study. Based on the research implications, the study proposes some managerial and administrative reforms to develop and sustain entrepreneurship orientation in the public sector organizations in Egypt.

The field study here has some limitations. Measures are based on perceptions and views of the executives at the Egyptian Electricity Holding Company, which explains the significant impact of entrepreneurial activities on organizational performance - with and without considering the moderating variables - in spite of what is proven concerning the minimal adoption of such activities at the same company. This dichotomy could be mainly due to the dependence of the empirical results on managers' perceptions (respondents' perceptual interpretations), rather than the actual situation.

Through both the theoretical and applied parts of this research, it reached the following results and recommendations:

\section{Results and Findings:}

First, the paper claims that public entrepreneurs act, in many ways, like private ones, although there are major differences related to the difficulty in measuring performance, ill-defined objectives, collective action problems, budget constraints, and the legal monopoly of coercion. Second, it notes that public and private entrepreneurship while typically treated in isolation, in fact they are linked in substantial ways. Public entrepreneurship is undertaken by individual actors, and at the same time the private action occurs in a public setting. As a result, the modern state contains elements of both public and private entrepreneurial behavior. In this context, the main findings here are:

- Entrepreneurship and innovation become a necessity in today's global business world, regardless of the organization's nature and scope, as the ultimate source of competitive advantage.

- The quality of performance is influenced by the extent to which an organization is entrepreneurial. Fostering the development of the entrepreneurial organization within government agencies and institutions will be a required step in stimulating innovation and enhancing performance in public sector. 
- An overall approach to the promotion of entrepreneurship rests on two primary pillars; improvement of entrepreneurial framework conditions and strengthening of entrepreneurial skills. Thereby, for entrepreneurship to thrive public organizations need to put in place an environment with supportive systems, structures, and resources that encourage employees to act entrepreneurially. On the other hand, continuing workers' education and training to constantly upgrade their skills is an important factor in maintaining entrepreneurial public organizations.

- From the case study findings, it is clear that entrepreneurship is a presented phenomenon at the Egyptian Electricity Holding Company, but the high percentage of those who disagree reflects the relatively weak levels of entrepreneurship, thus the adoption of entrepreneurship at the company is almost considered average. Also, the results imply that entrepreneurship has contributed to organizational performance at the company, as demonstrated by the positive linkage between the independent and dependent variables. As it is proven that the extent of entrepreneurship is positively related to organizational performance, or high levels of public entrepreneurship are associated with improvements in organizational performance of the Egyptian Electricity Holding Company.

- In addition, it is proven that the relationship between public entrepreneurship and organizational performance is moderated by some organizational characteristics at the Egyptian Electricity Holding Company, but unfortunately this influence is contradictory as noticed through the positive and negative effects in this regard. Since these factors have impacts on entrepreneurship in public sector generally, it is imperative that managers must be aware of them and make conscious decisions to take them into consideration, especially at the Egyptian Electricity Holding Company, hence fostering a climate of entrepreneurship. Such a climate would benefit public organizations and ultimately contribute to government performance in Egypt.

\section{Recommendations and Future Research:}

As governments mostly have a greater focus on new approaches and business models for identifying and harvesting gains from efficiency and effectiveness improvements in performance and service delivery, a relatively recent emerging policy agenda is that of contestability. In essence, this agenda actively spurs public sector personnel to apply entrepreneurial methods for realizing such benefits. Accordingly, the study made the following recommendations:

- Public managers should develop deliberate systems and mechanisms to boost, stimulate, and institutionalize entrepreneurship as a normal organizational practice and a basic performance improvement tool. Efforts should include provision of proper performance-based rewards and recognition, allowing employees' time off their officially-assigned tasks to work on creative ideas, and enhancing organization-wide communications.

- Strong organizational support is necessary for entrepreneurship, including top management support and offering financial assistance, since finance is essential for the adoption of entrepreneurship.

- The importance of understanding the historic role and effect of culture and values on the entrepreneurial behavior; is that the goal here should be to position the entrepreneur as a hero and to develop a culture that fosters innovation. 
- The importance of government policy towards entrepreneurship, as it shapes the environment in which entrepreneurial decisions are made. A key objective here must be to establish the utmost institutional, regulatory, and legal frameworks to provide appropriate conditions for entrepreneurship.

- Education also plays a considerable role in improving entrepreneurial activity, and this could be through enhancing the integration of entrepreneurship education into study programs at colleges and universities.

- The empirical results suggest that there should be more genuine efforts to promote entrepreneurship and stimulate it amongst employees at the Egyptian Electricity Holding Company, through developing the internal organizational conditions - especially those with negative impact and the insignificant ones - which definitely would reflect positively on the organizational performance. In this respect, the researcher emphasizes the urgency of establishing new administrative units that concern with and reward innovation, and encourage creative people and ideas within all public agencies in Egypt.

- Concerning future research, there is a need to conduct further comprehensive research to investigate the different organizational factors that influence the level and impact of entrepreneurship in public sector. This also induces the need to study the successes and constraints of the public sector in adopting entrepreneurial skills. As well, since this study focuses on entrepreneurship at one public organization only, future research can be conducted comparatively by taking into consideration other state-owned enterprises.

- Finally, future international entrepreneurship research could benefit a lot from including a perspective on cross-border activities to research on public entrepreneurship in multiple different countries. This will help to increase our understanding of the advantages and drivers of entrepreneurship across countries, thereby increasing the ability to generalize findings. 


\section{References}

- Acs, Z., D. Audretsch and R. Strim. (2009). Entrepreneurship, Growth and Public Policy, New York: Cambridge University Press.

- Adcroft, Andy and Robert Willis. (2016). The (Un)Intended Outcome of Performance Measurement in the Public Sector, Available at http://epubs.surrey.ac.uk/146746/3/1\%20Unintended\%20Outcomes\%20-\%20IJPSM\%20Author.pdf,11/8/2016.

- Antoncic, Bostjan and Cezar Scarlat. (2005). “Corporate Entrepreneurship and Organizational Performance: A Comparison between Slovenia and Romania", The $6^{\text {th }}$ International Conference of the Faculty of Management in Koper "Managing the Process of Globalization in New and Upcoming EU Members", Slovenia: (24-26 November), pp. 71-89.

- Antoncic, Bostjan and Otmar Zorn. (2004). “The Mediating Role of Corporate Entrepreneurship in the Organizational Support-Performance Relationship: An Empirical Examination", Managing Global Transitions, Vol. 2, No. 1, (Spring), pp. 5-14.

- Brinkley, lan. (2010). Innovation, Creativity and Entrepreneurship in 2020. London: The Work Foundation, (March).

- Carree, M. A. and A. R. Thurik, (2002), “The Impact of Entrepreneurship on Economic Growth”, in Zoltan Acs \& David Audretsch (eds.), International Handbook of Entrepreneurship Research, (July), Availableathttp://www.hadjarian.com/esterategic/tarjomeh/2-89-karafariny/1.pdf,18/6/2016.

- Cuervo, Alvaro; Domingo Ribeiro and Salvador Roig. (2016). Entrepreneurship: Concepts, Theoryand Perspective - Introduction, Available at http://www.uv.es/bcjauveg/docs/LibroCuervoRibeiroRoigIntroduction.pdf, 28/6/2016.

- Currie, G. M. Humphreys; D. Ucbasaran and S. McManus. (2008). “Entrepreneurial Leadership in the English Public Sector: Paradox or Possibility?", Public Administration, Vol. 86, No. 4, pp. 987-1008.

- Davidsson, P. F. Delmar and J. Wiklund. (2006). “Entrepreneurship as Growth; Growth as Entrepreneurship", in P. Davidsson; F. Delmar \& J. Wiklund (eds.), Entrepreneurship and the Growth of Firms, Cheltenham, UK: Edward Elgar Publisher, pp. 21-38.

- Elkjær, Jorgen Ravn. (2014). "Entrepreneurship in the Service Sector as a Product of Alertness and Judgment", The $\mathbf{9}^{\text {th }}$ Regional Innovation Policies Conference. Norway: University of Stavanger, (16-17 October).

- Fernando, R. Lalitha S. (2005). "Entrepreneurship in Delivery of Service in Public Sector Organization in Sri Lanka: Prospects for Administrative and Managerial Reforms", (NAPSIPAG) Annual Conference on "The Role of Public Administration in Building a Harmonious Society", Beijing: PRC, (5-7 December).

- Havinal, Veerabhadrappa. (2009). Management and Entrepreneurship. New Delhi: New Age International $(P)$ Ltd., Publishers.

- Hernandez, Jose G. Vargas. (2010). "The Role of Government in Enhancing Entrepreneurship of Small and Medium Enterprises for Economic Growth", Revista da Micro e Pequena Empresa, Campo Limpo Paulista, Vol. 4, No. 3, pp. 40-52. 
- Hortovanyi, Lilla. (2012). Entrepreneurial Management. Budapest: Aula Kiado Kft.

- Jones, Geoffrey and R. Daniel Wadhwani. (2006). “Entrepreneurship and Business History: Renewing the Research Agenda", HBS Working Papers, No. 07-007.

- Klein, Peter G.; Joseph T. Mahoney; Anita M. McGahan and Christos N. Pitelis. (2009). "Toward a Theory of Public Entrepreneurship", DRUID Working Papers, No. 10-07.

- La Nafie, Nur Alam; Umar Nimran; M. Al Musadieq and Imam Suyadi. (2014). “Organizational Internal Factors, Corporate Entrepreneurship, and Organizational Performance", European Journal of Business and Management, Vol. 6, No. 36, pp. 83-97.

- Llewellyn, Nick; Charles Edwards; Alan Lawton and Geoff Jones. (2016). Entrepreneurship and Public Service Management: Definitions, Competencies, Obstacles and Examples, Public Interest and Non-Profit Management Research Unit (PiN), Available at http://www7.open.ac.uk/ oubs/research/pdf/WP00_3.pdf, 30/6/2016.

- Lucy, Dibondo Nafula and Susan Were. (2014). “Challenges Faced by Public Sector Institutions in Adopting Entrepreneurial Skills: A Case Study of the Postal Corporation of Kenya", International Journal of Academic Research in Business and Social Sciences, Vol. 4, No. 10, (October), pp. 344-360.

- Matthews, Judy. (2016). Entrepreneurship in Public Sector: New Possibilities?, Available at http://eprints.qut.edu.au/71108/2/Matthews_-_Entrepreneurship_in_the_public_sector_-_ACERE.pdf, 20/5/2016.

- Mierlo, J. G. A. Van. (2002). “Public Entrepreneurship as Innovative Management Strategy in the Public Sector: A Public Choice-Approach", The $65^{\text {th }}$ Annual Conference of the Southern Economic Association, New Orleans: 18-20 November 1995, $2^{\text {nd }}$ Revision, (March).

- Mokaya, Samuel Obino. (2012). “Corporate Entrepreneurship and Organizational Performance: Theoretical Perspectives, Approaches and Outcomes", International Journal of Arts and Commerce, Vol. 1, No. 4, (September), pp. 133-143.

- Naude, Wim. (2013). “Entrepreneurship and Economic Development: Theory, Evidence and Policy", IZA Discussion Paper Series, No. 7507, (July).

- Naude, Wim; Adam Szirmai and Micheline Goedhuys. (2011). “Innovation and Entrepreneurship in Developing Countries", Policy Brief, (UNU-WIDER) United Nations University: World Institute for Development Economics Research, No. 1.

- Obaji, Nkem Okpa and Mercy Uche Olugu. (2014). "The Role of Government Policy in Entrepreneurship Development", Science Journal of Business and Management, Vol. 2, No. 4, pp. 109115.

- Otache, Innocent and Rosli Mahmood. (2015). “Corporate Entrepreneurship and Business Performance: The Role of External Environment and Organizational Culture: A Proposed Framework", Mediterranean Journal of Social Sciences, Vol. 6, No. 4, S3, (August), pp. 524-531.

- Pascual, Oriol, Arjen Van Klink, \& Julio Andres Rozo Grisales, (2011), Create Impact: Handbook for Sustainable Entrepreneurship, Enviu-Innovators in Sustainability. 
- Shamsuddin, Sofian; Jaizah Othman; Mohamad Asmady Shahadan and Zukarnain Zakaria. (2012). "The Dimensions of Corporate Entrepreneurship and the Performance of Established Organization", ACRNJournal of Entrepreneurship Perspectives, Vol. 1, Issue 2, (November), pp. 111-131.

- Shane, S. (2007). A General Theory of Entrepreneurship, The Individual-Opportunity Nexus, Cheltenham: Edward Elgar Publishing.

- Sherif, Shrifa Fouad and Alia Abdel Hamid Aaref. (2015). "Social Entrepreneurship Literacy and Capacity Building in Public Universities in Egypt", International Journal of Human Resource Management and Research (IJHRMR), Vol. 5, Issue 5, (October), pp. 1-16.

- Dr. Shrivastava, Sangya and Roopal Shrivastava. (2013). “Role of Entrepreneurship in Economic Development with Special Focus on Necessity Entrepreneurship and Opportunity Entrepreneurship", International Journal of Management and Social Sciences Research (IJMSSR), Vol. 2, No. 2, (February), pp. 1-5.

- Skica, Tomasz; Agnieszka Bem and Karolina Daszynska-Zygadlo. (2013). "The Role of Local Government in the Process of Entrepreneurship Development", Financial Internet Quarterly "e-Finanse", Vol. 9, No. 4, pp. 1-24.

- Stam, Erik, Chantal Hartog, Andre Van Stel, \& Roy Thurik. (2009). Ambitious Entrepreneurship, High-Growth Firms and Macroeconomic Growth, Zoetermeer: SCALES-initiative (Scientific Analysis of Entrepreneurship and SMEs), (September).

- Tosterud, Robert J. (2016). Entrepreneurship and the Public Sector, Available at http://www. jgbm.org/page/15\%20\%20Robert\%20J.\%20Tosterud.pdf, 3/6/2016.

- United Nations. (2004). "Entrepreneurship and Economic Development: The EMPRETEC Showcase", UN Conference on Trade and Development, Geneva: (May), Available at http://unctad. org/en/docs/webiteteb20043_en.pdf, 15/5/2016.

- Vicens, Lorenzo and Sergio Grullon. (2011). "Innovation and Entrepreneurship: A Model Based on Entrepreneur Development", (IDB) Discussion Papers, Inter-American Development Bank: Capital Markets and Financial Institutions Division, No. IDB-DP-202, (November).

- Wennekers, Sander; Andre Van Stel; Martin Carree and Roy Thurik. (2009). The Relationship between Entrepreneurship and Economic Development: Is It U-Shaped?, Zoetermeer: SCALES-initiative (Scientific Analysis of Entrepreneurship and SMEs), (July).

- Westrup, Ulrika. (2013). "Internal Entrepreneurship in the Public Sector: The Challenges of Integrating Innovative Project into the Regular Organization", Scandinavian Journal of Public Administration (SJPA), Vol. 16, No. 4, pp. 97-112.

- The Egyptian Electricity Holding Company's Official Website, Available at http://www.eehc. gov.eg/eehcportal/Eng/default.aspx, 1/8/2016. 


\section{Questionnaire}

\section{The Impact of Entrepreneurship on Performance in Public Sector Organizations with Application to the Egyptian Electricity Holding Company}

\section{Dear Sir/Madam...}

This questionnaire aims at studying the impact of public entrepreneurship on the organizational performance of the "Egyptian Electricity Holding Company". Therefore, it includes a number of items measure the different activities of entrepreneurship, and others measure the dimensions of organizational performance, and finally some items determine the organizational characteristics of the company.

Thank you for your kind response and cooperation which will contribute a lot to this research. Note that your answers will receive confidentiality, and they will be used only for the purposes of scientific research.

Kindly mark the most appropriate answer in front of each statement.

\section{First/Demographic Data:}

- Gender:

male

female

- Age:

under 35 years

35-less than 50 years

50 years or above

- Education:

post graduate studies

B.Sc.

- Title:

board member

sector head

less than B.Sc.

- Work Duration (at the Company): less than 10 years

25 years or above

Second/ Entrepreneurial Activities (Independent Variable):

\begin{tabular}{|c|c|c|c|c|}
\hline Sub-Variable & Statement & $\begin{array}{c}\text { Strongly } \\
\text { Agree }\end{array}$ & Neutral Disagree & $\begin{array}{l}\text { Strongly } \\
\text { Disagree }\end{array}$ \\
\hline \multirow{7}{*}{ Innovativeness } & \multicolumn{4}{|c|}{$\begin{array}{l}\text { Your company cares about accelerating the generation, dissemination, and application of innovative } \\
\text { and challengeable ideas, through frequently: }\end{array}$} \\
\hline & \multicolumn{4}{|c|}{$\begin{array}{l}\text { - introducing or developing new or existing products } \\
\text { and services. }\end{array}$} \\
\hline & \multicolumn{4}{|l|}{ - improving methods and processes of production. } \\
\hline & \multicolumn{4}{|l|}{ - establishing sub-organizations or units. } \\
\hline & \multicolumn{4}{|l|}{ - opening new projects or markets. } \\
\hline & \multicolumn{4}{|l|}{$\begin{array}{l}\text { 2. Your company is concerned about increasing its capacity } \\
\text { to innovate and to introduce novelty, through spending } \\
\text { on research and experimentation and developing } \\
\text { intellectual property rights for improving products, } \\
\text { services, technologies, managerial processes, and } \\
\text { administrative techniques. }\end{array}$} \\
\hline & \multicolumn{4}{|l|}{$\begin{array}{l}\text { Usually an innovation is carried out proactively rather } \\
\text { than reactively in your company, which means meeting } \\
\text { market opportunities by being the first mover or taking the } \\
\text { initiative and acting before others. }\end{array}$} \\
\hline
\end{tabular}




\begin{tabular}{|c|c|c|c|c|c|c|}
\hline Sub-Variable & Statement & $\begin{array}{c}\text { Strongly } \\
\text { Agree }\end{array}$ & Agree & Neutral & Disagree & $\begin{array}{l}\text { Strongly } \\
\text { Disagree }\end{array}$ \\
\hline \multirow[t]{3}{*}{$\begin{array}{l}\text { Opportunity } \\
\text { Seeking }\end{array}$} & $\begin{array}{l}\text { 4. Your company cares about creating or discovering, evaluating, } \\
\text { and utilizing profit opportunities - within the political } \\
\text { considerations - for providing new products, services, } \\
\text { processes, ways of organizing, and projects. }\end{array}$ & & & & & \\
\hline & $\begin{array}{l}\text { 5. In order to take advantage of market opportunities, } \\
\text { your company has a very high tendency towards } \\
\text { anticipating social needs or problems, responding } \\
\text { rapidly to the situation, and employing the best } \\
\text { alternatives for achieving particular outcomes. }\end{array}$ & & & & & \\
\hline & $\begin{array}{l}\text { 6. Your company often selects the opportunities to } \\
\text { be exploited depending on achieving the balance } \\
\text { between how valuable they are and how well they fit } \\
\text { to public resources. }\end{array}$ & & & & & \\
\hline \multirow[t]{3}{*}{ Risk Taking } & $\begin{array}{l}\text { 7. Your company has a high propensity to take the risk } \\
\text { associated with uncertainty, in order to maintain its } \\
\text { competitive edge and to respond to customers' needs. }\end{array}$ & & & & & \\
\hline & $\begin{array}{l}\text { 8. Your company always encourages employees to take } \\
\text { calculated risks by studying the feasibility of new } \\
\text { ideas, to increase its capacity to innovate. }\end{array}$ & & & & & \\
\hline & $\begin{array}{l}\text { 9. Your company usually encourages employees to take } \\
\text { responsibility for their actions by taking into account } \\
\text { possible losses while exploiting advantage of market } \\
\text { opportunities, as the investment risk here is in public } \\
\text { resources. }\end{array}$ & & & & & \\
\hline
\end{tabular}

\section{Third/Organizational Characteristics (Moderating Variable):}

\begin{tabular}{|c|c|c|c|c|c|c|}
\hline Sub-Variable & Statement & $\begin{array}{c}\text { Strongly } \\
\text { Agree }\end{array}$ & Agree & Neutral & Disagree & $\begin{array}{l}\text { Strongly } \\
\text { Disagree }\end{array}$ \\
\hline $\begin{array}{l}\text { Organizational } \\
\text { Structure }\end{array}$ & $\begin{array}{l}\text { 10. Your company has a strong supportive } \\
\text { (decentralized) structure and communication } \\
\text { system, allow management to behave in a flexible } \\
\text { and innovative way to undertake entrepreneurial } \\
\text { activities. }\end{array}$ & & & & & \\
\hline
\end{tabular}

Organizational 11. Your company has an entrepreneurial, open, Culture adaptive, and innovative culture supports trust, continuous learning, as well as risk taking, which is a main source of its competitive advantage.

Work Discretion 12. Your company usually encourages freedom in action and grants autonomy and independence to work units and employees to exert entrepreneurial efforts.

\section{Top}

Management

Support

Resources Availability
13. There is a true desire from top managers to facilitate and promote creativity and entrepreneurial activities within your company.

14. Your company is often ready to assign resources at once-whether financial, technical, or physical, including also time and knowledge-for innovation and entrepreneurial activities, in order to facilitate the implementation of experimental projects and research. 


\begin{tabular}{|c|c|c|c|c|c|c|}
\hline Sub-Variable & Statement & $\begin{array}{c}\text { Strongly } \\
\text { Agree }\end{array}$ & Agree & Neutral & Disagree & $\begin{array}{l}\text { Strongly } \\
\text { Disagree }\end{array}$ \\
\hline Reward System & $\begin{array}{l}\text { 15. In your company, there is an effective reward } \\
\text { and reinforcement system (monetary and non- } \\
\text { monetary), motivates employees to engage } \\
\text { in creative and entrepreneurial behavior, by } \\
\text { considering goals, feedback, and results-based } \\
\text { incentives. }\end{array}$ & & & & & \\
\hline $\begin{array}{c}\text { External } \\
\text { Environment }\end{array}$ & $\begin{array}{l}\text { 16. Your company has an encouraging and supportive } \\
\text { environment, not a hostile and restrictive one } \\
\text { exerts uncontrollable influences on development } \\
\text { and entrepreneurship efforts. }\end{array}$ & & & & & \\
\hline
\end{tabular}

\section{Fourth/Organizational Performance (Dependent Variable):}

\begin{tabular}{|c|c|c|c|}
\hline Sub-Variable & Statement & $\begin{array}{l}\text { Strongly } \\
\text { Agree }\end{array}$ & $\begin{array}{l}\text { Strongly } \\
\text { Disagree }\end{array}$ \\
\hline \multirow{9}{*}{$\begin{array}{l}\text { Financial } \\
\text { Performance }\end{array}$} & \multicolumn{3}{|c|}{ 17. Your company continuously looks for expansion and growth options, through: } \\
\hline & \multicolumn{3}{|l|}{ - increasing products and customers. } \\
\hline & \multicolumn{3}{|l|}{ - introducing new products and services. } \\
\hline & \multicolumn{3}{|l|}{ - recruiting new qualified employees. } \\
\hline & \multicolumn{3}{|l|}{ - opening new sub-units and organizations. } \\
\hline & \multicolumn{3}{|l|}{ - international expansion. } \\
\hline & \multicolumn{3}{|l|}{$\begin{array}{l}\text { 18. There is an increased demand for your company's } \\
\text { products and services, which reflects on the sales amount. }\end{array}$} \\
\hline & \multicolumn{3}{|l|}{$\begin{array}{l}\text { 19. Your company usually tries to use resources in new ways } \\
\text { to maximize productivity and efficiency, and to provide } \\
\text { products and services in competitive prices (the emphasis } \\
\text { on doing more with less). }\end{array}$} \\
\hline & \multicolumn{3}{|l|}{$\begin{array}{l}\text { 20. Your company often achieves relatively high revenues } \\
\text { and profitability rates, attributed to its way of using } \\
\text { available resources. }\end{array}$} \\
\hline $\begin{array}{l}\text { Non-Financial } \\
\text { Performance }\end{array}$ & \multicolumn{3}{|l|}{$\begin{array}{l}\text { 21. Employees tend to be highly committed to your company, } \\
\text { which reflects on their efficiency (cost of achievement), } \\
\text { effectiveness (quality and timing of achievement), and } \\
\text { behaviors (personal attitudes). }\end{array}$} \\
\hline & \multicolumn{3}{|l|}{$\begin{array}{l}\text { 22. There are relatively high levels of job satisfaction and } \\
\text { loyalty between your company's employees, which } \\
\text { reflects on their performance. }\end{array}$} \\
\hline & \multicolumn{3}{|l|}{$\begin{array}{l}\text { 23. Your company always cares about generating social } \\
\text { benefits, through finding ways to solve critical social } \\
\text { problems, offering more public choices and benefits, and } \\
\text { providing high-quality products and services to citizens. }\end{array}$} \\
\hline & \multicolumn{3}{|l|}{$\begin{array}{l}\text { 24. In general, your company is customer-oriented, focuses } \\
\text { its forces on communicating with, retaining, and better } \\
\text { serving customers, which reflects on their satisfaction. }\end{array}$} \\
\hline
\end{tabular}

